\title{
Las colaboraciones de Clarín en El Liberal a la luz de ocho cartas inéditas de Miguel Moya
}

\author{
Jesús Rubio JiméneZ \\ Universidad de Zaragoza
}

Título: Las colaboraciones de Clarín en El Liberal a la luz de ocho cartas inéditas de Miguel Moya.

Resumen: En este ensayo se analizan y editan ocho cartas de Miguel Moya y Leopoldo Alas, "Clarín", que arrojan nueva luz sobre la redacción y publicación en el diario El Liberal de varios de los cuentos más notables del asturiano, un corpus de su producción falto aún de estudio minucioso. Por otro lado, revelan las complejas relaciones de Clarín con sus editores en prensa, a quienes trataba de imponer sus criterios. Y, en fin, descubren otro aspecto del célebre autor de La Regenta: su actitud generosa y solidaria con otros compañeros de profesión, como Tomás Tuero y Luis París.

Palabras clave: Epistolario, Clarín, Miguel Moya, Tomás Tuero, Luis París.

Fecha de recepción: 1/5/2018.

Fecha de aceptación: 5/6/2018.
Title: The Contributions of Clarín in El Liberal in Light of Eight Unplushed Letters by Miguel Moya.

Abstract: In this paper I analyze and edit eight letters of Miguel Moya and Leopoldo Alas, "Clarín", which throw new light on the writing and journalistic edition at El Liberal of several of the most notable tales of the Asturian writer, a corpus of his production still lacking in detailed study. On the other hand, they reveal Clarín's complex relationships with its editors, to whom he tried to impose his criteria. And, finally, they discover another aspect of the famous author of La Regenta: his generous attitude and solidarity with other colleagues, such as Tomás Tuero and Luis París.

Key words: Epistolary, Clarín, Miguel Moya, Tomás Tuero, Luis París.

Date of Receipt: 1/5/2018.

Date of Approval: 5/6/2018.

Clarín publicó en El Liberal dos artículos y algunos cuentos que luego incorporó a El Señor y los demás, son cuentos (1893) y a Cuentos morales (1896). Su colaboración con dicho periódico se halla estrechamente ligada a los vaivenes de su amistad con Miguel Moya Ojanguren (1856-1920) mientras que este fue director del diario desde finales de los años ochenta 
y hasta que su trato se rompió tras el estreno de Teresa en marzo de $1895^{1}$. Las críticas del drama firmadas por Joaquín Arimón y algunos comentarios de Eusebio Blasco, aparecidos en El Liberal, suscitaron la reacción airada de Clarín, quien escribió una dolida carta de protesta que Moya no publicó $^{2}$ y, sin embargo, vio la luz en un comunicado al director del Heraldo de Madrid el 10 de abril de $1895^{3}$. Forma parte de la empecinada defensa que Clarín hizo de su drama, tratando de que se comprendiera y respondiendo así a quienes aprovecharon su fracaso para ajustar cuentas con él ${ }^{4}$. Tanto en la epístola como en el comunicado hacía gala de su afilada ironía para descalificar a Arimón como crítico, rebatiendo sus saetas con las tesis de

1 Sobre Miguel Moya: Don Miguel Moya. Rasgos biográficos, Madrid, Asociación de la Prensa, 1922; José Miguel González Soriano, "Miguel Moya y la revista La América”, ALEAU, 26 (2014), pp. 213-237; Margarita Márquez Padorno, Miguel Moya Ojanguren (1856-1920): talento, voluntad y reforma en la prensa española, Madrid, Ediciones de la Asociación de la Prensa de Madrid, 2015; y "El liberalismo en la prensa: Miguel Moya”, Historia contemporánea, 43 (2012), pp. 685-699.

2 La carta autógrafa ha sido recuperada por la revista El Cultural el 13 de junio de 2001, con una transcripción muy deficiente: "Clarín inédito. A Miguel Moya, director de El Liberal', El Cultural, 13 de junio de 2001.

3 En OC, IX, pp. 115-118, la versión más correcta extraída de Heraldo de Madrid. Poco después la reproduciría como "Polémica literaria", Heraldo de Baleares, 14-IV1895. Se citan las Obras completas de Leopoldo Alas, "Clarín", por la edición de Oviedo, Ediciones Nobel, 2002-2009, XII vols., remitiendo al volumen y página. Coordinación de Yvan Lissorgues y Jean François Botrel.

4 Sobre los avatares del drama y la querelle que suscitó véase Leonardo Romero Tobar, "Leopoldo Alas, Clarín", en Teresa, ensayo dramático. Avecilla. El hombre de los estrenos, Madrid, Castalia, 1976; Leopoldo Alas, "Clarín”, Obras completas. Varia, vol. XI, Oviedo, Ediciones Nobel, la sección referente a Teatro (pp. 1299-1414); y, con nuevas referencias, "Relación bibliográfica de reseńas y críticas de Teresa, la pieza teatral de Clarín”, en En buena compañia. Estudios en honor de Luciano García Lorenzo, coords. Joaquín Álvarez Barrientos, Óscar Cornago Bernal, Abraham Madroñal Durán, Carmen Menéndez-Onrubia, Madrid, CSIC, 2009, pp. 945-949. Una puesta al día del interés de Clarín en el arte escénico en Jesús Rubio Jiménez, "Clarín y el teatro", en Un siglo con Clarín. Exposición bibliográfica en el centenario de su muerte, eds. Antonio Fernández Insuela y Ramón Rodríguez Álvarez, Oviedo, Universidad de Oviedo, 2001, pp. 101-118; "Leopoldo Alas, Clarín y el teatro", Diecinueve, 7 (2001), pp. 21-60 (versión más extensa), y "Leopoldo Alas, Clarín, y la renovación teatral”, en Leopoldo Alas, un clásico contemporáneo (1901-2001), coords. Elena de Lorenzo Álvarez, Álvaro Ruiz de la Peńa Solar y Araceli Iravedra Valea, Oviedo, Universidad de Oviedo, 2002, II, pp. 595-628. 
otros cualificados escritores y plumillas que sí valoraron favorablemente el estreno de Teresa.

Había iniciado el litigio Joaquín Arimón con una reseña muy negativa del drama en "Teatro Español. La niña boba. Teresa”, publicada en El Liberal el 21 de marzo de 1895. Pero lo que terminó de exasperar los ánimos de Clarín contra los detractores de El Liberal fue que, una vez impresa su obra, insistieran en cebarse con él. En efecto, el 4 de abril de 1895, una vez leída Teresa, Arimón se reafirmó en su juicio, respondiendo así a las descalificaciones de Clarín 5 . Al día siguiente, Eusebio Blasco, en "Mi prólogo", lanzaría una nueva andanada de reproches, tomando esta vez como diana el prólogo con que el asturiano había puesto en circulación su drama y defendiéndose de sus ataques ${ }^{6}$.

Ambos artículos pusieron en el disparadero al autor de La Regenta, quien no tardaría en darle cumplida respuesta en las susodichas cartas, la primera no publicada, pero sí la segunda, bajo el expedito título de "Polémica literaria. Una carta de Clarín"7. Sin embargo, ni Arimón ni Blasco darían su brazo a torcer y continuaron atizando la polémica. Arimón volvería a insistir en que si el drama del asturiano hubiera triunfado nadie lo hubiera puesto en entredicho; y tampoco aceptó la petición que hacía Clarín de un jurado para valorar la pieza, achacando las quejas del dramaturgo a berrinches mal reprimidos ${ }^{8}$.

La réplica de Blasco se retrasó unos días, pero no fue menos irónica, empezando porque la estampó en "Broncápolis”, un artículo donde lamentaba que Madrid en esas fechas fuera escenario de constantes broncas tanto en el mundo de la política como en el de las letras ${ }^{9}$. No en vano, se hacía eco allí de la disputa que doña Emilia Pardo Bazán venía manteniendo con el periodista Roger de Flor, de La Correspondencia de España, quien se había burlado de lo incongruentes que resultaban los naranjos en un cuento bíblico de la escritora gallega. Esta le daría la réplica con algunas cartas en El Liberal ${ }^{10}$. Pero Blasco se reservó asimismo un par de

5 Joaquín Arimón, "A Clarín”, El Liberal, 4-IV-1895.

6 Eusebio Blasco, "Mi prólogo", El Liberal, 5-IV-1895.

7 "Una carta de Clarín", El Liberal, 14-IV-1895.

8 Joaquín Arimón, "Y vuelta con Clarín”, El Liberal, 15-IV-1895.

9 Eusebio Blasco, "Broncápolis", El Liberal, 21-IV-1895.

10 Emilia Pardo Bazán, "Naranjos en tiempos de Cristo", El Liberal, 16-IV-1895. 
rapapolvos para Clarín, el primero velado y acaso equívoco, mientras que el segundo sí que iba por derecho. En el primero,

Nuestro corresponsal de Oviedo nos telegrafía que el Sr. Deán de la Catedral está un "si es no es" grave a consecuencia de una coz que le dio anoche un literato de secano, amigo suyo.

Comentaba más adelante que en la Exposición que se iba a celebrar se incluían:

Juegos florales presididos por la Naranjero eximia y se dará el premio del Minuto a la mejor composición a Teresa (descanse en paz) y el premio Cánovas al mejor estudio "Sobre las causas de la decadencia del teatro nacional en los pueblos de menos de doscientos vecinos...".

El 24 de abril aún porfiaba Arimón en sus dicterios con "Mis paliques", ya que, a su juicio, "el currinche de Oviedo" no podía consolarse del fracaso de Teresa y trataba de rehabilitar su perdido crédito resucitando sus antiguos paliques y amenazando a sus lectores con una serie de latas donde explicaría como se debían hacer las obras de teatro y de crítica. Arimón anunciaba que opondría a estos paliques los suyos y, yendo todavía más lejos, ponía en duda la calidad de las clases de Clarín en la Universidad de Oviedo, hasta el punto de pedir que fuera depurado: "el muerto al hoyo" 11 . Era su cruel reacción a los paliques de Clarín en Madrid Cómico, durante los días previos, y a su solicitud de que debía ser cesado como crítico de teatros.

A decir verdad, las relaciones entre Miguel Moya y Clarín corrían algo tensas desde hacía tiempo. Y el asturiano abundó en sus diferencias en un "Palique" de Madrid Cómico (13 de abril de 1895), en el que afirmaba que Moya, que había andado durante años detrás de él para que colabora-

Nuevas cartas los días siguientes, 17-IV y 18-IV: "Y siguen los naranjos". Roger de Flor trató de cerrar el asunto con "El último naranjazo", El Liberal, 20-IV-1895. Su enfrentamiento continuó en los días siguientes.

11 Joaquín Arimón, "Mis paliques", El Liberal, 24-IV-1895. Continuó con "Mis paliques. Un juicio respetable", El Liberal, 21-V-1895. "Mis paliques. la clave del enigma", El Liberal, 2-VI-1895. 
se en el periódico con cuentos y artículos, permitía ahora que escribieran contra él en El Liberal. Clarín, tratando de dar mayor consistencia a su argumentación, volvió a descalificar a los críticos y se quejó de que el diario no contara con un especialista en teatro. Dedicó a Moya y Eusebio Blasco estas perlas:

A Moya. -Así como Sagasta explicó la crisis... bebiendo vasos de agua, usted podría explicarme (pero no lo necesito) por qué después de solicitar mi colaboración durante años y años, sin decirme que la deje, se deja de publicar mis cuentos... y se publican esas cosas de Arimón y de Blasco contra mí. Usted, querido amigo, no tiene culpa de nada. Nuestra amistad está por encima de todas esas miserias. Y de otras más dolorosas.

A Eusebio Blasco. - ¿ Se acuerda usted de las perrerías que me dijo de la crítica, aquella noche que le pagué aquella copa? Y sin esperar un sextercio, como usted decía, ¿se pasa al moro? Y otra cosa, ¿tan poco europeo cree usted que soy yo? Lea, sin ir más lejos el último número de la Revue de Deux Mondes. Con gente como usted hay que darse tono. De modo... que ¿`vuelvo a las andadas? Bueno. Los sextercios no faltarán. ¡Incauto! ¡Mal calculador! ¡Rosa amarilla! ${ }^{12}$.

Incluso en tan difíciles circunstancias salvaguardaba su afecto hacia Miguel Moya: "Nuestra amistad está por encima de todas esas miserias. Y de otras más dolorosas". Las dolorosas miserias a que se refería quedarán aclaradas más adelante en este ensayo.

Lanzado en su campaña de autodefensa, Clarín no dejó de escribir y publicar sus protestas allí donde pudo. Ante la negativa de difundir su carta en El Liberal, mandó otra el 10 de abril de 1895, que aparecería el día 14. Se lamentaba en ella de que no hubieran impreso su comunicado anterior y pedía que sometieran a un jurado imparcial su pieza, aceptando de antemano cualquier dictamen. Esta vez sí que se puso en letras de molde $^{13}$. Es imposible repetir y comentar en un puñado de páginas todos los textos que Clarín consagró durante aquellas semanas a la defensa de

12 Clarín, "Palique. Correspondencia particular", Madrid, Cómico, 13 de abril de 1895. En $O C$, IX, pp. 119-124 (p. 124). Trataba de convertir en ácido insulto una de sus más conocidas comedias -La rosa amarilla (1877)- al llamarlo "¡Rosa amarilla!".

13 Carta de Clarín al director de El Liberal. En OC, IX, pp. 125-126. 
Teresa. Y cuando la hoguera parecía que amainaba, reavivó el rescoldo en La Publicidad, cuando el fracaso madrileño del drama fue contrapesado por la buena acogida que tuvo en Barcelona ${ }^{14}$. A su estreno positivo añadía ahora los comentarios laudatorios que había recibido el drama tras su publicación, e incluso el hecho de que la corrección de pruebas la vigiló Benito Pérez Galdós ${ }^{15}$. Pero los chuzos desde El Liberal no cesaron y Clarín optó por alejarse del periódico ${ }^{16}$.

Lo que quiero resaltar es que Clarín escribía entonces dolido con Miguel Moya, toda vez que su trato había sido correcto en sus años mozos, durante los cuales habían asistido a las clases de Canalejas en la Universidad $^{17}$. Después, sus caminos discurrieron en cierto modo paralelos, sin grandes diferencias, y el escritor ahora se encontraba con que no aceptaba los cuentos que le remitía, y además incluía en su periódico artículos ofensivos contra su persona.

Las cartas que aquí edito permiten jalonar el discurrir de sus relaciones y los avatares de los cuentos del asturiano en El Liberal, donde Moya actuaba como director, atendiendo a fines esencialmente políticos; Clarín, por el contrario, consideraba que su reconocido nombre merecía un trato mejor. Era inevitable que chocaran, a pesar de su cordial relación desde la juventud.

Los datos muestran que Clarín siguió con interés y aprecio el auge de la carrera de su compañero de aulas universitarias. Así, el 29 de noviembre de 1879 se refería a él como uno de los más activos polemistas del Ateneo, considerándolo, en fin, una valiosa promesa para la política española ${ }^{18}$. Aunque Moya no llegó a gran figura, ocupó escaños en el Congreso a partir de 1886 , ligado estrechamente al Partido Liberal y en sintonía

14 OC, IX, pp. 132-137.

15 Así lo prueban algunas cartas cruzadas aquellos días. Véanse Jesús Rubio Jiménez, "El envés de la literatura. Galdós a través de sus cartas a Clarín", Anales Galdosianos (2005-2006), pp. 87-131; y Allan Smith y Jesús Rubio Jiménez, "Sesenta y seis cartas de Galdós a Clarín”, Anales galdosianos (2005-2006), pp. 133-197.

16 Joaquín Arimón, "Mis paliques. Teresa en Barcelona”, El Liberal, 2-VI-1895; "Mis paliques. El segundo entierro de Teresa", El Liberal, 20-VI-1895; y "Mis paliques. La autopsia de Clarín", El Liberal, 6-VII-1895.

17 Yvan Lissorgues, Leopoldo Alas, Clarin, en sus palabras (1852-1901), Oviedo, Ediciones Nobel, 2007, p. 120.

18 La Unión, 20-XI-1879. Véase Yvan Lissorgues, op. cit., pp. 273-274. 
con Emilio Castelar, su jefe de filas y con el tiempo también de Clarín. Y sobre todo fue un periodista influyente en la opinión pública desde que se incorporó a la redacción de El Liberal en mayo de 1879, tras haber rubricado brillantes artículos de costumbres en la revista La Linterna del Ateneo madrileño. Llamó entonces la atención de Fernanflor, quien le ofreció entrar en la redacción de El Liberal, donde se hizo un buen sitio con sus "Crónicas parlamentarias" y las colaboraciones en la sección literaria de "Los lunes de El Liberal", que coordinaba el propio Fernanflor desde su escisión de El Imparcial. En 1889 Miguel Moya fue nombrado director del periódico, cargo en el que permanecería hasta $1906^{19}$.

La relación con Miguel Moya trascendía lo personal, de ahí su presencia en uno de los periódicos más importantes de entonces, cercano a Castelar — su líder político ${ }^{20}$ — y que concedía amplio espacio a las letras. Clarín, siempre interesado en tener el mercado abierto, procuró contemporizar con su director hasta que este partió peras - e intereses comerciales-, y el asturiano se revolvió aireando trapos que habían estado ocultos (o semiocultos).

Fueron unas relaciones complejas de las que no sabemos demasiado y que tuvieron sus altibajos hasta su ruptura en 1895 . Se trataron durante años con aparente cordialidad y se habían hecho favores mutuos. Estas ocho cartas de Moya a Clarín nos ayudan a conocer mejor los entresijos de su relación y algunas curiosas circunstancias que acompańaron a la publicación de artículos y, sobre todo, a los cuentos del escritor en El Liberal. Como tantas veces, son parte de una correspondencia más amplia y eso que no contamos con las cartas de Clarín a su interlocutor, de modo que se adivina, más que se conoce, su diálogo durante aquellos años ${ }^{21}$.

De su cordialidad a comienzos de los años ochenta es buena muestra la primera carta que editamos, correspondiente al 4 de julio de 1881, cuando Clarín entregó a la estampa Solos de Clarín y Miguel Moya faci-

19 Sobre su trayectoria periodística completa, Margarita Márquez Padorno, "El liberalismo en la prensa: Miguel Moya”, Historia contemporánea, 43 (2012), pp. 685-699.

20 Jesús Rubio Jiménez y Antonio Deaño Gamallo, "Emilio Castelar y Leopoldo Alas, Clarín: entre la política y la literatura”, Archivum, LX (2012), pp. 9-57.

21 Los originales de las cartas se encuentran en el archivo de Dionisio Gamallo Fierros en Ribadeo (Lugo). En la transcripción regularizo la ortografía y he sustituido la abreviatura "V." por "usted". 
litó su reseña y difusión en El Liberal y La América. Se deduce de dicha epístola que el autor de La Regenta, según acostumbraba, había acudido a sus conocidos en la prensa para que lo reseñaran $[1]^{22}$. Y Moya le agradeció igualmente años después la atención que Clarín había prestado en 1890 a su libro Oradores politicos. Perfiles, al que el asturiano dedicó un par de artículos y una generosa carta que corrió de mano en mano por la redacción de El Liberal [2] $]^{23}$.

En 1885, no obstante, Clarín se dolería de que El Liberal no dijera nada de La Regenta tras llevar la novela un tiempo en circulación. Así, le escribía a Jacinto Octavio Picón:

El Imparcial no ha dicho palabra de mi novela, y eso no me extraña; El Liberal tampoco, y eso me extraña mucho. [...] ¿Qué les he hecho yo a los de El Liberal? ${ }^{24}$.

Le extrañaba — como digo — porque mantenía buenas relaciones con su director y no comprendía su silencio. Al año siguiente, sin embargo, Miguel Moya defendió la novela de los ataques de Guillermo Estrada, que la había descalificado desde su tradicionalismo integrista ${ }^{25}$.

El buen tono entre ellos se mantuvo en los años siguientes, y el 26 de abril de 1891 publicó Clarín en El Liberal el artículo "Efemérides", en forma de carta, a petición de su director, quien le había solicitado su opinión sobre las manifestaciones obreras del primero de mayo. Alas se posicionó aquí sobre la cuestión social, un asunto que estaba entonces de

22 En adelante remito a las cartas de Miguel Moya entre corchetes, siguiendo la numeración de esta edición.

23 No han sido incorporados a sus Obras completas. Clarín, "Oradores políticos: Perfiles, por Miguel Moya. -Sáenz Jubera, Hermanos-. Editores. -Madrid”, El Liberal, diario democrático de Menorca, 2645 (1-V-1890), p. 1; y "Oradores políticos. Perfiles, por Miguel Moya (Conclusión)", El Liberal, diario democrático de Menorca, 2653 (10-V-1890), p. 1. Este último con la indicación final "(El Globo)", indicando su probable procedencia. No he podido ver El Globo en estas fechas. Falta este año en la Biblioteca Nacional de España. Las estudio en "Clarín y el retrato satírico político (En torno a dos artículos olvidados de Clarín)”, en Homenaje a José Manuel González Herrán, Santander, Sociedad Marcelino Menéndez Pelayo, en prensa.

24 Yvan Lissorgues, op. cit., p. 451.

25 Ibidem, p. 451. 
actualidad $^{26}$. Consideró oportuna la campaña emprendida por El Liberal sobre la manifestación obrera del primero de mayo, y a propósito de la cuestión social afirmaba: "la considero sagrada y cosa santa que no ha de tocarse por la ignorancia" 27 . No había que cerrar los ojos ante la cruda realidad, sino estudiarla en profundidad y poner remedio a la miserable situación de las clases desfavorecidas, y para ello aportaba datos de los obreros de Asturias, subrayando cuánto le estaban haciendo reflexionar los mítines socialistas a los que asistía. Recogía a su vez ideas de sus participantes y sus posicionamientos frente a la burguesía. A Clarín le preocupaban estas confrontaciones y defendía un reformismo progresivo, que él llamaba "socialismo dinámico", frente a un "socialismo mecánico", enfrentándose de este modo al conservadurismo de Cánovas, empeñado en ignorar la gravedad de la cuestión social. Ofrecía así un planteamiento muy similar al que expondría meses después en su relato "Un jornalero", perfilando cuál debía ser el papel de los intelectuales en aquella situación, difícil y llena de mentises para los “obreros de la inteligencia”. Él mismo vivía intensamente aquellas contradicciones, las cuales se proyectan con frecuencia en sus escritos ${ }^{28}$.

El 31 de octubre de 1891, en su "Palique" de Madrid Cómico, agradeció a El Liberal y a La Justicia lo que habían dicho a su favor cuando fue agraviado desde La Epoca ${ }^{29}$. Esos embates respondían a sus diferentes tesis y, como de costumbre, Clarín se revolvía sacando a relucir viejas miserias de la profesión periodística.

En marzo de 1892, durante un viaje de a Madrid, y tras un incidente con Emilio Bobadilla que acabó en un duelo a espada donde Alas resultó

26 OC, VIII, pp. 135-139. Yvan Lissorgues, op. cit., pp. 601-602.

27 OC, VIII, p. 135.

28 Jean François Botrel, "El intelectual y la "pluma de hacer pesetas", en Obras completas. IX. Artículos (1895-1897), Oviedo, Nobel, 2005, pp. 7-36. Carolyn Richmond, "Los relatos de Clarín: una autobiografía ficticia", en Clarin: 100 años después. Un clásico contemporáneo, coords. Enrique Camacho, Yvan Lissorgues y Arturo Ramoneda, Madrid, Instituto Cervantes, 2001, pp. 143-153. Adolfo Sotelo Vázquez, "Los cuentos de Clarín, una autobiografía intelectual", en Emilia Pardo Bazán: los cuentos (II Simposio. A Coruña, 27, 28, 29 e 30 de setembro de 2005), eds. José Manuel González Herrán, Cristina Patiño Leirín y Ermitas Penas Varela, La Coruña, Real Academia Galega/Fundación Caixa Galicia, 2006, pp. 89-106.

29 OC, VIII, pp. 218-221. 
ligeramente herido en una caída, sus amigos le dieron un banquete para resarcirlo. Sus padrinos fueron en aquella ocasión Armando Palacio Valdés y Tomás Tuero. El ágape tuvo lugar el 22 de marzo en el Hotel Inglés. Entre otros se personaron Armando Palacio Valdés, Eduardo Palacio, Antonio Vico, Luis Morote y Miguel Moya ${ }^{30}$. Otro día de aquellos cenaron juntos Moya y Clarín en casa de Emilio Castelar. Fue en aquellas semanas cuando se concretó la colaboración de Clarín en El Liberal después de mucho tiempo de insistencia por parte de Miguel Moya para que se asomara a las páginas del periódico.

\section{Cuentos de Clarín en El Liberal}

Eran tiempos de buenas relaciones con el director de El Liberal; así se lo confesaba en una carta, el 12 de junio de 1892, a Luis París, joven y prometedor crítico literario. Tan buenas las consideraba que se ofreció a recomendarlo a Moya, apuntándole que lo tenía en gran estima y le iba a publicar cuentos, varios de los cuales tenía ya ideados y solo deseaba encontrar la paz veraniega del campo para escribirlos y sacarlos a la luz:

Si en El Liberal tardan mucho en cumplirle a usted lo prometido yo escribiré también a Moya, que me hace mucho caso. Para entonces ya le habré yo escrito varios cuentos y seré más de la casa; si bien la amistad y la confianza son ahora completas ${ }^{31}$.

30 José María Martínez Cachero, "Leopoldo Alas Clarín. Sobre tres episodios de su vida”, edición digital en la Biblioteca Virtual Miguel de Cervantes (Universidad de Alicante) (http://www.cervantesvirtual.com/obra-visor/leopoldo-alas-clarn---sobretres-episodios-de-su-vida-0/html/ff4ad57a-82b1-11df-acc7-002185ce6064_4.html: consultado el 20 de mayo de 2018). La Correspondencia de España incluyó el 23 de marzo un breve suelto, "El banquete de anoche", cifrando en 36 los asistentes, entre los que mencionaba a Antonio Vico, Grilo, Palacio Valdés, Sánchez Pastor, Matoses, Taboada, Llana, Sánchez de León, Bofill, Sierra, Sellés, Cavia, Palacio, Laserna, Pons, Sánchez Pérez, Rueda, Padilla, Vallés. Sobre la difusión de sus cuentos en la prensa, véase Jean François Botrel, "La poética periodística de Clarín: el ejemplo de los cuentos”, en Literatura hispánica y prensa periódica (1875-1931), Actas del Congreso Internacional. Lugo (25-28 de noviembre de 2008), coords. Javier Serrano Alonso y Amparo de Juan Bolufer, Lugo, Universidade de Santiago de Compostela, 2009, pp. 115-135.

31 Jean François Botrel, "De periodista a periodista: diez cartas de "Clarín» a Luis 
En efecto, en la paz de Guimarán escribió Clarín ese verano “¡Adiós, cordera!” y "El Señor”, cuyo escenario corresponde a la citada aldea. Moya publicó el 27 de julio de 1892 “AAdiós, cordera!” en El Liberal, según le había prometido ${ }^{32}$. Por el contrario, “El Señor” no saldría de los tórculos hasta los días 31 octubre y 3 de noviembre; y lo haría en Los lunes de El Imparcial, es decir, en un periódico de la competencia.

Presumiblemente habían surgido ya algunas diferencias entre ellos, debidas a sus dispares criterios acerca de la extensión de los cuentos. Moya valoraba el asunto como director del periódico y en función del espacio del que disponía, mientras que Clarín los desarrollaba según sus necesidades narrativas. El Liberal seguía una acertada política de incluir folletines y textos breves en dos secciones: "Cuentos ajenos", donde difundían traducciones de relatos de otras lenguas, en especial franceses; $y$ "Cuentos propios”, que servían de promoción a escritores espańoles en unos años durante los cuales el cuento literario experimentaba una profunda transformación.

Miguel Moya administraba el espacio dedicado a la literatura —el periódico era ante todo un instrumento de propaganda de un partido- en función de las posibilidades que ofrecían la actualidad política y las secciones fijas de información general. Parte del contenido de sus cartas a Clarín consiste en explicarle esta situación y sus limitaciones para incluir sus cuentos que, además, eran más extensos de lo habitual.

Alas trataba de obtener de sus trabajos literarios el mayor rendimiento, lo que le llevó a dejar de colaborar en Madrid Cómico, toda vez que no le pagaban lo suficiente ${ }^{33}$, o a buscar la gestión de sus artículos y cuentos a través de la Agencia Almodóbar, cuya sede estaba en la madrileña calle

París", Letras de Deusto, 32 (mayo-agosto, 1985), pp. 171-184. Ahora en OC, XII, p. 363. Las cartas de Luis París en la presentación de mi edición de su libro Gente nueva. Critica inductiva, Sevilla, Athenaica, 2017, pp. 12-20.

32 Agustín Coletes Blanco, Clarín y Carreño. Candás y su Concejo en la vida y obra de Leopoldo Alas, Carreño, Ayuntamiento de Carreño, 2001, pp. 132-134. El cuento aparece fechado en El Liberal en "Guimorán [sic] 22 de julio de 1892".

33 Carta a Luis París, OC, XII, p. 363: "Por último, sabrá usted que he dejado Madrid Cómico, no por nada sino porque a mí me despachaba con treinta duros al mes, a Taboada con 20 (secreto todo esto) y mientras la plana mayor (sin modestia de la redacción) tenía que contentarse con 12 mil reales, el seńor Sinesio, excelente persona pero demasiado empresario, se quedó algunos años con 5 ó 6 mil duros". 
Sol, no 9, que los distribuía en periódicos provinciales con el reclamo de "Colaboración inédita" ${ }^{4}$. Esto no obstaba para que un mismo escrito se publicara en varios lugares. Baste apenas un ejemplo: el 7 de junio de 1892 apareció un "Palique" en El Liberal de Alicante con una reseña de poeta argentino Calixto Oyuela, tal como descubrió Cecilio Alonso. Y poco después, en La Nación de Buenos Aires, el 27 de junio de 1892. Sin embargo, se había difundido antes en La Opinión de Valladolid, el 4 de junio de $1892^{35}$. Clarín acudió a esta agencia para distribuir sus trabajos porque en los grandes diarios no se lo valoraba bien, y estaba en permanente discusión con sus responsables por el cobro de sus colaboraciones y la extensión de sus textos.

La impresión en El Liberal el 14 de noviembre de 1892 del cuento "Protesto" dio lugar a algunos comentarios muy esclarecedores al respecto:

Recibí ayer el cuento de usted Protesto y hoy se publica ${ }^{36}$. Esto le demostrará a usted lo que ya le he dicho, que tenía verdaderas ansias de dar en la sección de Cuentos propios la firma de usted ${ }^{37}$. Protesto

34 Ofrece información sobre esta agencia Ángeles Ezama Gil, "Literatura periodística y dispersión: algunas colaboraciones olvidadas de Clarín en la prensa de provincias", Revista de Literatura, LXXVII, 153 (2015), pp. 211-247 (p. 212). Fundada en 1890 , gestionaba cuentos originales de escritores españoles ilustrados y también traducidos, folletines, retratos, grabados y otros servicios útiles para la prensa.

35 OC, VIII, 366-369. Y cabe añadir otras publicaciones del mismo palique en La crónica meridional (Almería), 7-VI-1892; El isleño, periódico de intereses materiales (Palma de Mallorca), 11600 (8-VI-1892); La Rioja, 1011 (4-VI-1892); Diario de Tenerife, 13-VII-1892. No se ha rastreado lo suficiente la presencia de Clarín en la prensa provincial en aquellos meses, al margen de que ya ha arrojado, no obstante, frutos interesantes. Véanse Ángeles Ezama Gil, op cit., y Jesús Rubio Jiménez, "Leopoldo Alas, Clarín, en la prensa vallisoletana: las colaboraciones en La Opinión (1892-1901)", Boletín de la Biblioteca Menéndez Pelayo; en prensa.

36 Clarín, "Protesto", El Liberal, 14-XI-1892, recopilado en El Señor y lo demás son cuentos.

37 La sección se había iniciado el 18 de junio de 1892 como ampliación de otra -"Cuentos ajenos"-, donde publicaban traducciones de cuentos de otras lenguas. En un suelto, "Nuestros cuentos", explicaban ese día su intención de alternar la nueva sección con la anterior y difundir obras de autores españoles. Daban una lista de colaboradores comprometidos: Miguel de los Santos Álvarez, Leopoldo Alas, José Castro y Serrano, José Echegaray, Emilio Ferrari, José Fernández Bremón, Isidoro Fernández Flórez, Salvador López Guijarro, Armando Palacio Valdés, Ramón Rodríguez Correa, Eugenio Sellés y 
hace tres columnas, una más que los más largos que publicamos, [los] sucesivos —yo celebraré que sean muchos — no deben tener más de seis cuartillas.

Ya sé, ya sé que tiene usted razón que le sobra cuando dice que esto es desnaturalizar el género. Pero si ahora que, aun sin estar reunidas las cortes, no podemos dedicar más de diez o doce líneas a asuntos de verdadero interés general, publicamos cuentos de más de dos columnas, desnaturalizaríamos el periódico, que tiene como usted sabe un folletín, que hacer una plana y una revista cómica que casi todos los días llega a una columna.

Si los días que los accesorios nos obliguen a quitar el folletín puedo dar en folletón en letra de 8 los dos cuentos de usted que tengo aquí lo haré gustosísimo. De otro modo se los enviaré certificados [4].

De las palabras de Moya se desprenden sus diferentes posiciones. Aun así, no acabó de encontrar el momento de incluir aquellos relatos de más lago aliento. Estas situaciones fueron tensando sus relaciones a medida que pasaban los días y los cuentos no aparecían. A principios de 1893, Clarín volvió a Madrid Cómico y, una vez ajustadas sus condiciones económicas, le escribió a finales de enero a Sinesio Delgado:

El primer artículo, para que lo tenga usted en tiempo oportuno, puede usted ir a pedírselo de mi parte (o escribirle) a Moya, El Liberal. Dígale esto: que si él no piensa publicar mi artículo "Diálogo Edificante", que se lo dé a usted, y que si piensa publicar ese que le dé el cuento titulado Benedictino, o el cuento titulado Rivales que no ha publicado aún por largos. Y que yo arreglaré cuentas con $E l$ Liberal ${ }^{\beta 8}$.

En efecto, el debut de Clarín en Madrid Cómico, con su firma, fue "Diálogo edificante", el 4 de febrero de 1893, recogido después en Palique

Juan Valera; además de la lista de sus redactores y colaboradores: Joaquín Arimón, Mariano de Cavia, Joaquín Dicenta, Eduardo Palacio, Ángel Pulido, José Roure, Rafael Salillas, Eusebio Sierra y Tomás Tuero; y señalaban que "también hemos solicitado la cooperación y esperamos su respuesta, que nos atrevemos a esperar sea favorable, de los señores" Narciso Campillo, Gaspar Núñez de Arce, Narciso Oller, Emilia Pardo Bazán, José María de Pereda. De casi todos publicaron cuentos a lo largo de aquel año.

$O C$, XII, p. 379. 
(1894). Tampoco los otros dos cuentos aducidos tuvieron un mejor destino, ya que "Rivales" y "Benedictino" saldrían algunos meses después en La Ilustración Española y Americana (8 de julio de 1893) y en Los Lunes de El Imparcial (19 de junio de 1893). Es posible que Moya se resistiera a entregárselos a Sinesio Delgado, esperando la oportunidad y el espacio suficientes para publicarlos.

Con el editor Manuel Fernández Lasanta comprometió por aquel entonces un libro con esos y otros relatos: El Señor y lo demás son cuentos. Sería iluminado por el asturiano Pedro Rivera; e incluso recomendó a este pintor a Sinesio Delgado para que ilustrara con sus "monos" sus cuentos de Madrid Cómico ${ }^{39}$. Finalmente, sin embargo, el libro apareció sin estampas, aunque Leopoldo Alas daría precisas indicaciones sobre su organización al editor y le fue remitiendo los textos ${ }^{40}$. El seguimiento de la entrega de originales ayuda a clarificar las dificultades para publicar los cuentos en la prensa y las diferencias con Moya. Con sus más y sus menos, la vía de difusión en El Liberal seguía abierta y allí apareció "La yernocracia” el 15 de enero de 1893, que más tarde fue incorporado a $E l$ Señor y los demás son cuentos. Pero no había la fluidez necesaria y Clarín se resistiría a aceptar que sus relatos permanecieran inéditos tanto tiempo. Debió de recibir con impaciencia la carta de Moya del 4 de abril de 1893, donde le ponía al tanto de sus intenciones de dar a conocer "La Rosa de oro" apenas le quedara hueco entre las entregas de un folletín:

Pues bien. En uno de esos días procuraré dar en folletón La Rosa de Oro que no es cuento de las dimensiones del Centauro sino doble ${ }^{41}$. Y vea usted lo que influye esto de las dimensiones en la publicación de un artículo aunque también se burle usted. De ser de dos columnas La rosa de Oro lo hubiera publicado el mismo día que lo recibí. [6]

39 Yvan Lissorgues, op. cit., pp. 650-660.

40 El plan preciso para su publicación se lo expuso por carta al editor. Texto en $O C$, XII, pp. 396-399. Véase Gonzalo Sobejano, "Introducción” a Leopoldo Alas, "Clarín”, El Señor y lo demás son cuentos, Madrid, Espasa Calpe, 1988.

41 Clarín, "El Centauro", El Liberal, 22-III-1893, luego recopilado en El Señor y los demás son cuentos (1893). 
El cuento acabó en las páginas de Los Lunes de El Imparcial el 10 de julio de 1893. Pero no debió de resultar del agrado de Clarín, que continuaba, no obstante, enviando nuevos cuentos. El 6 de octubre de 1893, Moya le escribió acerca de diferentes asuntos, entre otros la publicación de un cuento en ausencia suya y su liquidación [7]. Debe tratarse de "Boroña", que vería la luz en El Liberal el día 6 de septiembre de 1893.

También la última carta que rescato aquí, correspondiente al 1 de mayo de 1894, contiene alguna información sobre "El Torso", cuyo original había recibido Moya y que no dio a los tórculos hasta el 17 de aquel mes, a pesar de su entusiasmo hacia el relato [8]. Es decir, seguían los intercambios, pero sin la agilidad que Clarín hubiera deseado. Y por ello no sorprende encontrar referencias en otras cartas a este ir y venir desde la redacción de El Liberal a otras rotativas, donde encontraban postrero acomodo. Escribía el asturiano a Sinesio Delgado en 1894:

Háganle [¿̨háganme?] el favor de ir a ver a Moya o escribirle diciéndole de mi parte (y además le escribo yo) que le entregue inmediatamente porque tiene usted prisa, el cuento que le di hace tanto tiempo para El Liberal y que no se publicó por largo, titulado $\mathrm{La}$ trampa. Con eso tiene usted cuento mío para el día que lo necesite.

Si Moya lo perdió avíseme ${ }^{42}$.

El pequeño epistolario que edito, por tanto, arroja interesante luz sobre la manera en que se difundieron los cuentos de Clarín en aquellos años. Aunque eran de veras estimados y su nombre servía como indudable reclamo para los periódicos, seguían prevaleciendo los criterios de crear opinión en las cabeceras, muy dependientes de los grupos políticos que las financiaban. Ese era el fin fundamental de aquellas gacetas, mientras que las letras ocupaban un lugar subsidiario, o al menos no tan relevante. Si faltaba espacio, la primera en caer era siempre la literatura de entretenimiento. Clarín, que ya gozaba de un prestigio bien asentado, se resistía a las presiones de Moya para que escribiera cuentos más breves. Muy al contrario, los desarrollaba con la extensión que juzgaba necesaria, afanándose en buscar -en casos concretos- diarios que los acogieran sin objeciones, y desde luego obteniendo beneficios de su trabajo. De ahí los

42 En $O C$, XII, p. 439. 
continuos tira y afloja entre el editor y escritor en sus colaboraciones en El Liberal.

Un asunto diferente es el referido en la última carta que exhumo: la inclusión de una larga serie de semblanzas en El Liberal, durante unos meses de 1894, para ofrecer a sus lectores una galería de personajes notables, resaltando su ejemplaridad. En las notas que acompañan a la misiva aclaro algunas circunstancias del contenido de esta sección.

\section{Tomás Tuero, redactor de EL LiberaL}

Un tercer asunto ocupa la mayor parte de las cartas que edito en este artículo: la entrada — por recomendación de Clarínv de Tomás Tuero en la redacción de El Liberal, donde trabajó durante los últimos meses de su vida, antes de fallecer tuberculoso. El 9 de junio de 1891 le escribió Moya al autor de La Regenta comunicándole que había convertido su petición en realidad y que Tuero ya había ingresado en el periódico:

Mi muy querido amigo: Está usted servido. Tuero ha entrado en la redacción de El Liberal y ha empezado a escribir en este periódico con general aplauso ${ }^{43}$. Digo que está usted servido viendo su carta de usted anterior a la admisión de Tuero por que recomendaban a este para mí, además de sus obras, el concepto que usted tiene de él desde hace mucho tiempo, que yo conozco, y que me parece tan carińoso como justo. [3]

Clarín debió de descansar aliviado sabiendo que sus gestiones en pro de su buen amigo, siempre muy necesitado de ingresos y enfermo, habían llegado a buen puerto. Llevaba tiempo animándolo a perseverar en su vocación de escritor, oficio que Tuero cada vez detestaba más y con el que ya no cumplía sino por la obligación de tener algunos ingresos para ir tirando. Alas había llegado a dirigirle dos cartas abiertas a Tuero en La

43 Tomás Tuero (1851-1893), escritor y periodista asturiano, amigo desde los años de juventud de Clarín, quien lo consideró su "amigo del alma". Véase Manuel Fernández Avello, Tomás Tuero. La leyenda de un periodista, Oviedo, Instituto de Estudios Asturianos, 1958. 
Correspondencia de España los días 7 y 14 de diciembre de 1890, a fin de que siguiera escribiendo y respondiendo a sus preguntas en un momento en que quería abandonar el periodismo político para volcarse en la crítica y la narrativa: "La audacia en el arte. A Don Tomás Tuero en El Pais" ${ }^{44}$.

El repaso de las páginas de El Liberal durante los meses siguientes, sin embargo, arroja un escaso número de escritos firmados por Tomás Tuero. Se dedicó sobre todo a trabajos de redactor sin firma, ya que había renunciado a hacerse un nombre ${ }^{45}$. Y además, su mala salud se agravó rápidamente. El 13 de noviembre de 1891 Moya refería que Tuero había faltado algunos días en la redacción por motivos de salud [4]. Y del 10 de diciembre de 1892 data otra carta relacionada con el agravamiento de su dolencia; el director ponía al día a Clarín sobre cómo se habían desarrollado los acontecimientos en las fechas inmediatamente anteriores:

Tan pronto como me convencí de la gravedad de Tuero pregunté a Francos Rodríguez que lo visitaba diariamente, aunque no como médico, lo que podría hacerse. Me dijo Francos que se imponía con urgencia para Tuero un cambio de clima y que a su juicio debía irse a Alicante o Málaga.

Usted conoce mejor que nadie a Tuero, usted sabe que su talento extraordinario y sus condiciones brillantes de escritor, resultan empalidecidas por su poca fe y poca constancia en el trabajo. Resulta de aquí, y usted no se enojará que le hable con esta franqueza, que desde que entró en El Liberal no ha tenido ocasión de hacer ninguna campaña digna de él.

Esto limita mucho mi acción para alcanzar grandes cosas. Más en su beneficio. Pero antes de que me viniera la carta de usted que conservaré siempre como elocuente prueba de lo que usted vale, ya había

44 Las dos cartas abiertas citadas en $O C$, VII, pp. 1161-1164 y 1170-1173. La correspondencia de Tomás Tuero con Clarín, conservada en el archivo de Dionisio Gamallo Fierros, puede verse en Jesús Rubio Jiménez y Antonio Deaño Gamallo, Clarín y sus compañeros de viaje asturianos: José Quevedo, Tomás Tuero y Pío Rubin. La grisura de la vida moderna, Oviedo, Servicio de Publicaciones de la Universidad de Oviedo, 2018, pp. 69-94.

45 Apenas hallo ya en 1892 los siguientes: Tomás Tuero, "Teatro de La Princesa", El Liberal, 21-IV-1892; "Teatro Español", El Liberal, 24-IV-1892; "Desde Borines", El Liberal, 18-VI-1892; "En Asturias. Buyeres de Nava”, El Liberal, 30-VII-1892, y "Crónica libre. Renan”, El Liberal, 3-X-1892. 
logrado que se pase a Tuero el sueldo íntegro dos meses a contar desde que salga de Madrid para ver si se restablece. Pasado este tiempo, que claro está yo he de alargar cuanto me sea posible, veremos lo que puede hacerse. No dude usted de que yo haré cuanto pueda. [5]

José Francos Rodríguez, aunque Moya indica que no lo visitaba como galeno, había estudiado medicina y, por tanto, su diagnóstico no ofrecía muchas dudas. La situación era crítica y Moya no sabía cuanto tiempo podría soportarla económicamente. La salud de Tuero se iba deteriorando y trataron de convencerlo para que viajara a un lugar cálido para reponerse, salvando así los difíciles meses del invierno: Málaga o Alicante. No lograron persuadirlo y el asturiano optó finalmente por desplazarse a Oviedo en un estado calamitoso el 17 de diciembre, donde moriría dos días después. Tanto Armando Palacio Valdés como Moya y otros miembros de la redacción de El Liberal, se volcaron en ayudarlo, pero este trato deferente no alcanzó para que mejorara su mermada salud. Clarín informó de la muerte del escritor mediante un telegrama a los miembros de la redacción de El Liberal, que lo incluyó el día 20 en el suelto "Tomás Tuero":

No nos hacíamos nosotros ilusiones en cuanto a la enfermedad traidora que iba, poco a poco, y a nuestra vista, minando su existencia, pero siempre creímos que daría alguna tregua mayor, y hasta esperamos que el aire de su tierra natal, que con ansias tan grandes quería respirar, aliviaría algo su dolencia, ya que curarla era imposible.

[...] No es hora esta de juzgar a Tuero como escritor, ni, aunque lo fuera, nos encontraríamos nosotros con la serenidad de ánimo necesaria para hacerlo. En este momento no acertaríamos a exponer ningún juicio — si acertáramos no habríamos querido a Tuero como le quisimos- y solo nos alcanza deplorar su muerte, sobre todo en esta redacción donde cuanto hay nos le recuerda.

Nadie sabe el esfuerzo de voluntad que tenemos que hacer para convencernos de que Tuero no volverá a compartir nuestras tareas, que en muchas ocasiones fue él con su ingenio quien las hizo gratas.

Nuestro amigo Leopoldo Alas, que es quien nos telegrafía la triste noticia de la muerte de Tuero, y que fue el compañero inseparable de toda su vida, nos dice que murió sin agonía. ¡Tardía compen- 
sación del destino, que tanto amargó sus últimos días, haciéndole presentir la muerte!

Al día siguiente informaron del entierro con una breve nota recibida por telégrafo. Tuvo lugar a las cuatro de la tarde, con asistencia de representantes de todos los partidos republicanos, del claustro universitario, de la prensa y de sus camaradas. Llevaron las cintas, periodistas y amigos ${ }^{46}$. El 27 de diciembre de 1892, Clarín publicó el artículo necrológico ("Tomás Tuero") en El Liberal, de nuevo en forma de carta, ahora dirigida a Mariano de Cavia — que formaba parte de la redacción del periódicoEs una sentida semblanza del compañero ${ }^{47}$. Las circunstancias eran muy dolorosas para todos ellos:

Escribir para la imprenta de cosas tan íntimas como esta desgracia, me molesta, me repugna, me parece una afectación, algo falso. Si me rindo a los ruegos cariñosos de nuestro querido y también desgraciado Moya, y a los de usted, expresados en estos telegramas que les agradecemos infinito la familia de Tuero y yo, es con la condición de que usted repase esta carta y no publique de ella sino lo que crea oportuno y digno de la prensa. No estoy yo por esta clase de selecciones ${ }^{48}$.

Clarín tenía mucha fe en la valía del amigo muerto, aunque la obra impresa que dejaba no era demasiada. Lo había defendido y ayudado siempre. Para Alas el mejor Tuero, a quien consideraba ante todo un sońador y un poeta, había quedado inédito, y por ello manifestaba su intención de reunir sus escritos para demostrarlo. Algo que no hizo y que continúa pendiente. Trazó sin embargo una semblanza sobre su trayectoria personal, su vida entregada al periodismo con gran pasión, durante sus primeros años, en los que compartió cabeceras con Clarín — La Nueva Asturias, Rabagás, El Solfeo-, y después en periódicos madrileños: Gil Blas, La Iberia, El País o en El Liberal, adonde llegó ya muy mermado de facultades a causa de sus achaques. Era un gran lector y completaba sus

46 "El entierro de Tuero (Por telégrafo)", El Liberal, 21-XII-1892.

47 OC, VIII, pp. 457-463.

48 OC, VIII, p. 457. 
ingresos con traducciones de novelas y dramas franceses, pero sin tener una visión práctica de la vida:

Quería vivir la poesía, no escribirla; y pocas cosas habrá más sinceras que la repugnancia que a Tuero le producía la literatura de oficio...

Pero no prosigo, mi querido Cavia; si yo entrara a analizar el carácter de Tuero, la historia de su alma, de sus ilusiones, de su desiderata..., no concluiría nunca. Podría llenar un volumen y quedarme con lo más en el cerebro... No es extraño; Tuero pensaba mucho, sentía mucho, yo fui su confidente de más de veinte años, y tengo todavía la vida del corazón y de la mente llena de su recuerdo. No he de escribir aquí una miserable elegía, sin pathos repugnante; diré solo que su muerte la siento yo por mí, a lo egoísta, como una especie de hemiplejia moral ${ }^{49}$.

Encontró incluso la forma de agradecer en su carta el generoso trato que le dispensaron en El Liberal, habida cuenta de la situación en que llegó y de cómo vivió sus últimos meses, prácticamente de la caridad y la munificencia de Miguel Moya:

Por último, ¡ay, sí! Por último, le han tenido ustedes en El Liberal, donde no necesitan que yo les diga ni lo perezoso que era su compañero, ni lo bien que escribía ${ }^{50}$.

El quisquilloso Clarín era, sin embargo, un hombre que se desvivía por sus amigos y hasta por los allegados de estos. Un rastro de dicha condición queda en las cartas que edito, testimonio de cómo se ocupó en tratar de conseguir para el hermano de Tuero un puesto como vendedor del periódico o algún trabajo en la administración que aliviara su extrema pobreza [6].

El fiasco de las críticas a Teresa, al que me he referido al comienzo, desconcertó al autor de La Regenta y lo llevó a enfrentarse con sus colegas de El Liberal, rompiendo las posibilidades de que su firma continuara desfilando por sus páginas. Así lo haría saber en La Publicidad (24 de abril de 1895$)^{51}$. Pero, aun así, nunca olvidó el generoso proceder de Moya

49 OC, VIII, p. 462.

50 OC, VIII, p. 461.

51 Yvan Lissorgues, op. cit., p. 745. 
para con su amigo, de modo que cobran todo su sentido las palabras que he transcrito más arriba, diferenciando entre sus discrepancias con el director de El Liberal y el comportamiento de este con Tuero: "Nuestra amistad está por encima de todas esas miserias. Y de otras más dolorosas”.

Mientras preparaba la publicación de su nuevo libro de relatos Cuentos morales, se dio cuenta Clarín de que le faltaban originales o copias de algunos de los relatos. No le planteaba ningún problema rescatar los aparecidos en Madrid Cómico, pero no tenía copia de "Boroña", que era de los que más habían gustado en Asturias; de modo que se vio en la necesidad de pedirle a Sinesio Delgado que fuera a buscarlo a la redacción de El Liberal. Lo mismo ocurría con el original de "Para vicios". Y no se anduvo con tapujos:

Ya que usted es del Liberal le agradeceré que busque en la colección de este el cuento propio (mío) titulado Boroña que no tengo y que quiero sin falta incluir en la colección que va a publicarme La España Editorial: no quiero prescindir de este cuento porque por aquí fue de los que más gustaron. Es muy fácil buscarlo: 1894, últimos días de agosto y acaso (más probable) primera quincena de septiembre. En todo caso de quince a quince. Si hay ejemplares sueltos envíeme uno, al precio que sea, si no que un escribiente lo copie y usted dígame el importe de este trabajo.

Si puede ser, en el mismo mes de agosto (o julio) 1894, busque otro cuento titulado Para vicios y envíemelo también.

Mire que es un favor que le agradeceré mucho. Si no estuviera mal (requetemal) con Moya, es claro que no le molestaría ${ }^{52}$.

El siempre suspicaz Clarín terminó por romper sus lazos con Miguel Moya. Debieron de cruzar en aquellas semanas algunas cartas donde se quebraría el siempre delgado hilo de su amistad. Divergían en sus intereses, el escritor asturiano encajó mal su fracaso teatral y, además, vivía requemado con el director de El Liberal, quien por razones de espacio no otorgaba la suficiente atención a los relatos que le iba mandando. Es un claro ejemplo de la divergencia entre literatura y negocio editorial que con tanta frecuencia se produce en el mundo de la prensa.

52 En $O C$, XII, p. 501. 


\section{Cartas de Miguel de Moya a Leopoldo Alas, Clarín}

Sr. D. Leopoldo Alas

Mi distinguido y carińoso amigo: No sabe usted cuanto le agradezco su última carta. Mi luto, con serlo por la muerte de una persona querida, no indica sin embargo la pérdida de uno de los pocos cariños irremplazables de la vida. Cuando la desgracia se espera, el dolor es menos intenso que cuando nos sorprende y la desgracia que hoy lamento, la esperaba. Ha muerto una abuela mía anciana ya, y mucho tiempo hace enferma y achacosa. No por esto dejo de sentirlo y de estimar con toda el alma las frases de consuelo que usted me dirige.

Flórez ha recibido el libro de usted. Le he leído cuanto usted me dice y me encarga le dé a usted las gracias por lo que dice de sus amigos Fernanflor y el Lunático ${ }^{53}$. Me ha prometido escribir el artículo crítico lo antes posible. Yo me encargo de recordarle no mi ofrecimiento, que de seguro no lo olvida, pero sí que lo cumpla pronto.

En la próxima revista de La América dedicaré un párrafo, o mejor dicho, un apunte a Solos de Clarin $^{54}$. Esto no quitará para que con más espacio y tiempo hable en otro periódico de usted. Los articulistas y los críticos no coleccionan sus trabajos por el gusto solo de verlos reunidos

53 Isidoro Fernández Flórez (1840-1902) fue más conocido por su seudónimo Fernanflor. Periodista, crítico de arte y humorista, comenzó su carrera en La Ilustración de Madrid (1870) y luego fue redactor de El Imparcial, haciéndose célebre por las crónicas que firmaba como "Un lunático". Creó Los lunes de El Imparcial. En 1879, junto con otros periodistas, fundó El Liberal, donde desarrolló una intensa labor crítica y publicó numerosos cuentos.

54 Clarín, Solos de Clarin, Madrid, 1882. Miguel Moya cumplió su palabra en su "Revista general", La América, 8-VII-1881, donde escribió: "Juzgar al Sr. Alas es como alumbrar al sol; [...] con esto solo quiero decir que siendo el crítico verdaderamente temible de la literatura contemporánea, asombra la sola idea de criticarle”. Prefiere tomar algunos elogios de Echegaray del prólogo del libro y destaca el capítulo "Cavilaciones" por sus pensamientos. 
ni por el provecho de cobrar dos mil reales ${ }^{55}$. Los articulistas y los críticos que con frecuencia dedican artículos de una columna y aun más a obras de escaso interés suelen llegar al término de una carrera en que ningún periódico les haya consagrado cuatro líneas. Este olvido de la prensa que no del público es lo que los libros colección evitan, Son un motivo para que el crítico sea criticado. Si los que hablan mal de la crítica comprendieran cuanto el crítico de verdad la desea cuando llega este caso, en vez de censurarla la saludarían llenos de gratitud y de cariño.

¿Y Armando? ${ }^{56}$ Le debo una noticia en El Liberal que publicaré mañana mismo. El no haber encontrado la carta en que me daba el encargo me ha impedido cumplirle.

Sabe usted que le quiere y admira su afmo. a[migo]

Miguel Moya Julio 4 / 1881

[El Diputado a Cortes

Por Ponce]

Sr. D. Leopoldo Alas

Mi querido amigo: Dos sorpresas a cual más agradable para mí ha producido por lo que veo mi libro de Perfiles ${ }^{57}$. Una, la de usted, encontrándome mejor escritor de lo que imaginaba, otra la mía, encontrándole a usted mucho mejor amigo mío de lo que yo creía. Y ahora que no vengan

55 Miguel Moya preservó algunos de sus artículos recopilados. Por entonces publicó la colección Puntos de vista, Madrid, 1881.

56 Se refiere al novelista Armando Palacio Valdés (1853-1938), amigo común desde sus años de estudiantes universitarios.

57 Miguel Moya, Oradores políticos. (Perfiles), Madrid, Sáenz de Jubera Hermanos, 1890. El libro se puso en circulación los últimos días de abril. Se anuncia en $E l$ Liberal el 26 de abril de 1890 -"Miguel Moya, Oradores políticos (Perfiles)"- como una colección de semblanzas, ilustradas con fotograbados realizados por Laporta. Su portada es un notable dibujo de Manuel Domínguez. 
muchas sorpresas de estas: no las doy viendo lo que usted es y sabiendo lo que usted vale por todos los discursos que han pronunciado y pronunciarán en lo que les queda de vida Martos y Cánovas ${ }^{58}$.

Le debo a usted ¡y cuidado si es deuda! una carta y dos artículos ${ }^{59}$. La carta ha corrido de mano en mano por la redacción de El Liberal sin que todavía hayamos logrado traducirla del todo: los artículos me han valido muchos elogios que no esperaba.

No faltan diputados comensales (¿?) (pues aunque usted les trate a ellos mal, ellos le admiran a usted mucho) que me digan en broma en el salón de conferencias recordando algo que usted decía en su primer artículo:

- ¿Me deja usted reclinar mi cabeza en su hombro?

Yo no les dejo — claro está- pero me acuerdo de lo que debo a la amistad de usted y con esto quedo contentísimo.

Ya sabe usted mi lema:

¡Guerra a los generales y viva Clarín!

Suyo afmo. reconocido amigo y admirador

Miguel Moya Abril 29 / 1890

58 Antonio Cánovas de Castillo (1828-1897), el líder del partido conservador, fue una de las bestias negras de Clarín, quien escribió incesantemente contra él, incluyendo uno de sus conocidos folletos: Cánovas y su tiempo (188). Cristino Martos (18301893), abogado. Presidió el Congreso de los Diputados; fue ministro de Estado durante la Regencia de Espartero y, durante el reinado de Amadeo I, ministro de Gracia y Justicia en la I República. Se trata de otro de los políticos a los que Clarín marcó de cerca. Falleció en enero de 1893 y Alas le dedicó una breve necrología en "Revista mínima", La Publicidad, 1-II-1893, que sintetiza sus puntos de vista sobre su trayectoria. En OC, VIII, 487-490.

59 Miguel Moya debió de enviarle un ejemplar a Clarín y este le escribió una carta acusando recibo y dos artículos que llenaron de satisfacción a Moya. Las alusiones humorísticas encuentran su explicación en estos artículos. 
[El Liberal

PERIÓDICO POLÍTICO

ALMUDENA, 2

Dirección]

Sr. D. Leopoldo Alas

Mi muy querido amigo: Está usted servido. Tuero ha entrado en la redacción de El Liberal y ha empezado a escribir en este periódico con general aplauso. Digo que está usted servido viendo su carta de usted anterior a la admisión de Tuero por que recomendaban a este para mí, además de sus obras, el concepto que usted tiene de él desde hace mucho tiempo, que yo conozco, y que me parece tan carińoso como justo.

Publicaré con mucho gusto el fragmento que me ofrece de Su único hijo y todo lo que usted quiera ${ }^{60}$. Debo advertirle que ahora la campaña de los exámenes y la causa de Pepe el Huevero me llena mucho espacio, para que se explique usted que solo por esto desee que el fragmento no sea tan extenso como yo querría, única manera de que no se retrase su publicación $n^{61}$.

60 Clarín, Su único hijo, Madrid, 1891. Era una forma de darle publicidad a la novela. El Nacional (Buenos Aires) ofreció un fragmento el 6 de febrero de 1891. Y también en El Liberal, el 5 de julio de 189. Bajo el título "Su único hijo" encontramos un suelto elogioso sobre Clarín y su novela, seguido del capítulo XI de la misma.

61 Durante gran parte del mes de junio El Liberal publicó informaciones sobre los exámenes y artículos de opinión; verbigracia los de Rafael Salillas, "Matusalén académico”, El Liberal, 8-VI-1891, o Rafael Altamira, "Los exámenes. En el extranjero”, El Liberal, 17-VI-1891. No he visto, sin embargo, colaboraciones firmadas por los mencionados en la carta. Pepe "el Huevero" era el apodo de José Díaz de Velasco, empleado del Ayuntamiento de Madrid que fue detenido en junio de 1889 por su implicación en diferentes delitos como alteración del padrón municipal, pagos indebidos, etc. La memoria que redactó al final de la investigación el gobernador civil de Madrid provocó la dimisión del alcalde y de varios concejales. El escándalo se prolongaría durante meses. Clarín se refirió al asunto en "Argentinas", El Nacional (Buenos Aires), 4-VIII-1890. En OC, VII, pp. 1082-1085. 
Me dijo Tuero que González se venía por aquí; su carta de hoy me lo confirma; deseo sea tan pronto como acabe con la tarea de los exámenes. Y a propósito de exámenes, si quieren usted, Builla [sic], Aramburu y Posada decirnos algo se lo agradeceremos ${ }^{62}$. Pérez Pujol, Giner, Lamarca, Calderón y otros (muy pocos, no es número lo que se necesita) lo harán también ${ }^{63}$.

Sabe usted que de veras le quiere y le admira s. af. amigo

\author{
Miguel Moya \\ Junio 9 / 1891
}

62 Miembros del claustro de la Universidad de Oviedo, simpatizantes con el krausismo y de mentalidad reformista: Adolfo Álvarez Buylla González Alegre (1850-1927), jurista y catedrático de Economía Política en la Universidad de Valladolid y después de Economía Política y Hacienda Pública en la de Oviedo. Fundó un Seminario de Sociología en esta última al que acudían obreros y fue una de las bases de la Universidad Popular posterior. Félix Pío de Aramburu y Zuloaga (1848-1923), jurista y escritor asturiano; catedrático en la Universidad de Oviedo de Historia y Elementos de Derecho Romano. Adolfo González Posada (1860-1944), jurista, sociólogo, traductor y escritor; discípulo de Francisco Giner de los Ríos. Catedrático de Derecho Político en la Universidad de Oviedo. Acerca de sus relaciones con Clarín, véase Jesús Rubio Jiménez y Antonio Deaño Gamallo, "Adolfo Posada y Clarín. Correspondencia”, Cartas Hispánicas (Fundación Lázaro Galdiano), 2015 (http://www. bibliotecalazarogaldiano.es/carhis/001.html: consultado el 24 de mayo de 2018).

63 Francisco Giner de los Ríos, con quien Clarín mantuvo una larga relación, y otros afines a sus ideas. Acerca de las relaciones entre Alas y el fundador de la ILE, véase Jesús Rubio Jiménez y Antonio Deaño Gamallo, "Francisco Giner de los Ríos y Leopoldo Alas, Clarín: nuevas cartas inéditas", Boletín de la Biblioteca Menéndez Pelayo, LXXXV (2009), pp. 265-292. Eduardo Pérez Pujol, rector de la Universidad de Valencia y prestigioso catedrático de Historia del Derecho, afecto a las tesis krausistas y siempre muy atento a las condiciones de vida de la clase obrera; Alfredo Calderón y Arana (1850-1907), periodista español, había estudiado derecho en Madrid, donde fue seguidor de Julián Sanz del Río y de Fernando de Castro, catedrático en la Institución Libre de Enseñanza; colaboró en la prensa republicana y dirigió La Justicia; y, en fin, a Carlos Navarro Lamarca, periodista argentino, asimismo simpatizante de los krausistas y colaborador en diferentes periódicos en aquellos ańos. Clarín al menos se pronunció sobre los exámenes en su "Palique" Madrid Cómico, 13-VI-1891. Opiniones contundentes en OC, VIII, pp. 155-156. 
Mi querido Alas: Recibí ayer el cuento de usted Protesto y hoy se publi$\mathrm{ca}^{65}$. Esto le demostrará a usted lo que ya le he dicho, que tenía verdaderas ansias de dar en la sección de Cuentos propios la firma de usted. Protesto hace tres columnas, una más que los más largos que publicamos, [los] sucesivos —yo celebraré que sean muchos— no deben tener más de seis cuartillas.

Ya sé, ya sé que tiene usted razón que le sobra cuando dice que esto es desnaturalizar el género. Pero si ahora que, aun sin estar reunidas las cortes, no podemos dedicar más de diez o doce líneas a asuntos de verdadero interés general, publicamos cuentos de más de dos columnas, desnaturalizaríamos el periódico, que tiene como usted sabe un folletín, que hacer una plana y una revista cómica que casi todos los días llega a una columna.

Si los días que los accesorios nos obliguen a quitar el folletín puedo dar en folletón en letra de 8 los dos cuentos de usted que tengo aquí lo haré gustosísimo. De otro modo se los enviaré certificados ${ }^{66}$.

Tuero anda bastante delicado estos días. Hace siete u ocho que por prescripción facultativa no viene por la redacción.

Muy bien, admirablemente bien Protesto.

Sabe usted que le quiere muy de veras y le admira siempre s. af. a.

Miguel Moya ¿Y el viaje definitivo?

64 Sin fechar, pero por la indicación de la fecha de publicación del cuento "Protesto" correspondería al 13 de noviembre de 1892. Clarín ya había publicado “iAdiós, cordera!" el 27 de julio de 1892 en El Liberal, pero es partir de "Protesto" cuando en la sección de "Cuentos propios" se incluyen relatos suyos, hasta su distanciamiento del periódico en 1895.

65 Clarín, "Protesto", El Liberal, 14-XI-1892.

66 Puede referirse a los cuentos que publicó en los meses siguientes: Clarín, "La yernocracia”, 15-I-1893; "El Centauro", 22-III-1893; "La Ronca", 19-IV-1893; "Cristales", El Liberal, 24-VII-1893, luego en Cuentos morales, 1896. O bien a cuentos que no dio a la estampa por su extensión y que luego mandó recoger a Sinesio Delgado, caso de "Benedictino" o "Rivales".

De este libro, véase la cuidada edición de Jean-François Botrel: Leopoldo Alas "Clarín", Cuentos morales, Madrid, Cátedra, 2012. 
[El Liberal

PERIÓDICO POLÍTICO

ALMUDENA, 2

Redacción]

Mi querido Alas: No he contestado a usted antes porque los sucesos políticos de estos días me tienen más abrumado de trabajo que nunca, y porque el poco tiempo de que he podido disponer he tenido que consagrarle a los cuidados del menor de mis hijos gravemente enfermo.

Tan pronto como me convencí de la gravedad de Tuero pregunté a Francos Rodríguez que lo visitaba diariamente, aunque no como médico, lo que podría hacerse ${ }^{67}$. Me dijo Francos que se imponía con urgencia para Tuero un cambio de clima y que a su juicio debía irse a Alicante o Málaga.

Usted conoce mejor que nadie a Tuero, usted sabe que su talento extraordinario y sus condiciones brillantes de escritor, resultan empalidecidas por su poca fe y poca constancia en el trabajo. Resulta de aquí, y usted no se enojará que le hable con esta franqueza, que desde que entró en $E l$ Liberal no ha tenido ocasión de hacer ninguna campaña digna de él.

Esto limita mucho mi acción para alcanzar grandes cosas. Más en su beneficio. Pero antes de que me viniera la carta de usted que conservaré siempre como elocuente prueba de lo que usted vale, ya había logrado que se pase a Tuero el sueldo íntegro dos meses a contar desde que salga de Madrid para ver si se restablece. Pasado este tiempo, que claro está yo he

67 José Francos Rodríguez (1862-1931), médico, periodista, escritor y político que trabajaba en aquel momento en la redacción de El Liberal. Fue director del Heraldo de Madrid y después alcalde de Madrid, ministro de Instrucción Pública y de Gracia y Justicia. Clarín enderezó dos cartas abiertas a Tomás Tuero en La Correspondencia de España los días 7 y 14 de diciembre de 1890, animándole a seguir escribiendo y respondiendo a sus preguntas: "La audacia en el arte. A Don Tomás Tuero en $E l$ Pais”. En OC, VII, pp. 1161-1164 y 1170-1173. 
de alargar cuanto me sea posible, veremos lo que puede hacerse. No dude usted de que yo haré cuanto pueda.

Armando cree que Tuero debe irse a Oviedo: yo no. Ni ese clima le conviene ni esa vida tampoco. En un pueblecillo de Málaga o Alicante con mucho sol, y comida sana, y poca conversación puede pasarlo bien hasta que aquí mejore el tiempo que ahora está muy frío. En Oviedo tendría el calor de la amistad pero a mi juicio en el estado en que Tuero se encuentra uno ve que, de las cosas que más daño le hacen es hablar mucho y ahí no dejará de hablar ni un minuto ${ }^{68}$.

Deseo saber en definitiva la opinión de usted.

Sabe usted lo mucho que le quiere y le admira su afmo. amigo

Miguel Moya

Diciembre 10 /1892

El Liberal

PERIÓDICO POLÍTICO

ALMUDENA, 2

\section{Dirección]}

Mi querido Alas: Las cuentas de usted son las nuestras. No se preocupe usted de ellas poco ni mucho. Sobre los cuentos que nos envíe como bien le parezca seguro de que no hemos de dejar mal su firma nunca.

En lo que falta de mes y con objeto de que llegue hasta los primeros días del próximo la novela El conde de Montecristo, cosa utilísima para la cobranza $(\dot{i})$, habrá que quitar cuatro o cinco días el folletín, cosa que no afecta $(\dot{\zeta})$ más aunque usted se sirve de ello, que imprimir por un año el artículo de fondo ${ }^{69}$.

68 Tomás Tuero viajó a Oviedo el 17 de diciembre, llegando a la capital asturiana en un estado lastimoso. Falleció dos días después. Clarín publicó su sentida necrología (“Tomás Tuero") en El Liberal del 27 de diciembre de 1892.

69 Clarín no estaba de acuerdo con esta política editorial. Quizás sus reflexiones sobre 
Pues bien. En uno de esos días procuraré dar en folletón La Rosa de Oro que no es cuento de las dimensiones del Centauro sino doble ${ }^{70}$.

Y vea usted lo que influye esto de las dimensiones en la publicación de un artículo aunque también se burle usted. De ser de dos columnas $L a$ rosa de Oro lo hubiera publicado el mismo día que lo recibíi ${ }^{71}$.

El último cuento de Picón tenía cerca de tres columnas y lo tuve en cartera cerca de un mes $^{72}$.

He hablado con el gerente de la venta de El Liberal en Oviedo ${ }^{73}$. Usted sabe que esto de los vendedores es de su exclusiva competencia. Le he visto poco propicio a complacernos siquiera su respuesta no haya sido definitiva.

Ahora bien. Como lo que usted desea y yo deseo con usted es que el hermano de Tuero tenga que antes de nada un medio decoroso de vivir, conviene que antes de ver bien nada le pregunte usted si tendría inconveniente en encargarse de la venta de El Liberal en otro punto cualquiera o si puede solicitarse para él algún puesto determinado en la administración pública. Lo primero por si hay alguna capital donde no da gusto el vendedor por falta de actividad o su temor en el pago. Lo segundo para demostrarle a usted el verdadero interés que tengo en servirle.

Y nada más. Suyo amigo y admirador que [ilegible]

Miguel Moya Abril 171893

la novela de folletín en Las Provincias, 21-V-1893 no sean ajenas a estas circunstancias: reclamaba que no se perdiera el sentido común literario y artístico, a fin de que toda aquella generación no se volviera tonta; a su juicio, la reacción folletinesca era lo más deplorable que se podía inventar.

70 Clarín, "El Centauro", El Liberal, 22-III-1893; y "La Ronca” el 19-IV. Ambos en El Señor y los demás son cuentos (1893).

71 "La Rosa de oro" acabó publicándose en Los Lunes de El Imparcial el 10 de julio de 1893, siendo recogido después en El Señor y los demás son cuentos (1893).

72 Jacinto Octavio Picón (1852-1923), escritor, pintor y crítico de arte; autor de novelas y cuentos de tendencia naturalista.

73 Respondía a una petición de Clarín orientada a ayudar al hermano de Tomás Tuero. La familia vivía en unas condiciones de extrema pobreza. 
[El Liberal

PERIÓDICO POLÍTICO

ALMUDENA, 2

Dirección]

Mi querido Alas: Le aceptaré la letra. ¡No faltaba más! El último cuento de usted se publicó en ausencia mía ${ }^{74}$. Estuve en San Sebastián al mismo tiempo que Sagasta y fui testigo de todos los horrores que allí hubo ${ }^{75}$. Después llamado por mi madre gravemente enferma, pasé unos días en san Pedro de Pinatar, un pueblecito de Murcia muy próximo a la finca de Campoamor ${ }^{76}$.

Di la noticia de la traducción (¿) de Superchería ya tarde, cuando recibí la carta de usted.

Tiene usted razón en lo que dice del libro de El Señor.

Arimón iba a hacer un suelto, hasta le anunció que le tenía comentado a usted que iba a escribir un artículo y entre unos y otros el libro no se ha [ilegible] y luego quedaría según lo que quiera. Le advierto a usted que estos días enreda mucho pero que ha estado cerca de un mes sin salir de su casa con la excusa de una enfermedad tan grave como la de 1886.

No dirá usted que no soy generoso para escribirle.

Le quiere muy de veras y de veras le admira su afmo.

Miguel Moya Octubre $6 / 1893$

74 Clarín, "Boroña", El Liberal, 6-IX-1893, después en Cuentos morales, 1896; "La imperfecta casada", El Liberal, 25-X-1893, después en Cuentos morales, 1896; "Don Patricio o el premio gordo en Melilla”, El Liberal, 23-XII-1893, después en Cuentos morales, 1896. En 1894 siguió enviando otros cuentos: "Ordalías", El Liberal, 19III-1894; "El Torso", El Liberal, 17-V-1894; "Para vicios", El Liberal, 20-VII-1894.

75 Práxedes Mateo Sagasta y Escolar (1825-1903) fue ingeniero de caminos y político español, miembro del partido Liberal y presidente del Consejo de Ministros en varias ocasiones.

76 Ramón de Campoamor (1817-1901), poeta y político español. Sobre las relaciones de Campoamor con Clarín, véase Jesús Rubio Jiménez y Antonio Deaño Gamallo, "29 cartas inéditas de Ramón de Campoamor, a Clarín”, Archivum, LXIII (2013), pp. 7-63. 
[El Liberal

PERIÓDICO POLÍTICO

ALMUDENA, 2

Dirección]

Mi querido Alas: Buen recorrido, bueno, el que da usted ayer a Pompeyo Gener en Los Lunes de El Imparcial ${ }^{77}$. Y para tranquilidad de su conciencia cónstele a usted que todavía nos ha sabido a poco a muchos espíritus benévolos. ¡Si será malo D. Pompeyo!

Publicaré el cuento titulado El Torso muy pronto: dentro de la primera quincena de este mes: es hermosísimo ${ }^{78}$.

Para el Plutarco tengo en cartera más de veinte artículos, entre ellos algunos muy notables: Dickens por Galdós, Rosales por Palmaroli, Hernán Cortés por Balart, D. Enrique de Villena por Menéndez Pelayo, Da Juana la Loca por Gener y Felipe $2^{\circ}$ por Núñez de Arce ${ }^{79}$.

77 Clarín, "Revista literaria. Sumario: Santa Teresa. Her life and times, by Gabriela Cunninghame Graham. - Literaturas malsanas, por Pompeyo Gener", Los Lunes de El Imparcial, 30-IV-1894. En OC, VIII, pp. 734-743. Ataca con dureza el libro de Gener a causa de sus ideas y de su escritura. Pompeyo Gener (1846?-1920) fue un periodista y escritor nacionalista catalán, autor de una copiosa pero confusa obra ensayística. Moya contradice, sin embargo, esta opinión negativa del catalán, incluyéndolo entre los colaboradores de su Plutarco, donde firmó una semblanza de doña Juana la Loca. Finalmente, con todo, fue Fernanflor quien firmaría esta semblanza. Anteriormente he visto su firma en El Liberal: Pompeyo Gener, "L 'Argent por Emilio Zola”, El Liberal, 22-VI-1891; con una pequeña serie de artículos sobre Tolstoi: "Tolstoi tránsfuga del nihilismo" (1-VII-1891); "Tolstoi místico iluminado" (11VII-1891) y "Tolstoi asceta (22-VII-1891).

78 Cumplió su palabra: Clarín, "El Torso", El Liberal, 17-V-1894; luego, en Cuentos morales, 1896.

79 La sección de divulgación histórica Plutarco del pueblo se inició el 25 de enero de 1894 con un artículo programático donde se explica que incluirán biografías de bienhechores del género humano que sirvan de ejemplo a los lectores. Su conocimiento ayuda a comprobar el progreso humano y los poetas y filósofos ensanchan su conciencia. El 5 de mayo anunciaron que tenían muchos trabajos en cartera para la sección. De Menéndez Pelayo habían publicado "El autor de La Celestina", El Liberal, 6-IV-1894, 
Escriben también otras láminas Echegaray, Castelar y Campoamor ${ }^{80}$. Y daremos este mes probablemente uno de iiSagasta!! El presidente del Consejo está entusiasmado con la sección y quiere colaborar en ella ${ }^{81}$. Su artículo sobre un ingeniero ilustre (no ha dicho cual) será un efecto periodístico de mucha resonancia. Porque si Sagasta no se ha enterado todavía de lo que ha pasado en Valencia ni de lo que ha ocurrido en Melilla y se entera de algo para servir a El Liberal se convierte en el primer ministerial del Plutarco ¿No le parece a usted?

Esta sección ha gustado mucho y hay que explotarla un poco. Cuando se agote, qué ocasión de hablar y hablaremos con mucho gusto de todos los proyectos de usted ${ }^{82}$.

Le quiere y le estima su Amigo afmo.

Miguel Moya

Mayo 11894

pero no he visto la nueva colaboración sobre Villena que anuncia. De lo adelantado aquí, hasta finales de septiembre aparecieron: Fernanflor, "Da Juana la Loca”, El Liberal, 28-V-1894, y Vicente Palmaroli, "Eduardo Rosales", El Liberal, 25-VI-1894. Ignoro si en fechas posteriores aparecieron las colaboraciones de Galdós, Balart y Núnez de Arce. A finales de septiembre la sección estaba agotada.

80 Emilio Castelar abrió esta sección con "Gutenberg”, El Liberal, 3-II-1894. Después fue uno de los colaboradores más asiduos: "El Papa Celestino V", El Liberal, 2-III-1894; "El conquistador de Toledo", El Liberal, 23-III-1894; "Un maestro de escuela (Pestalozzi)", El Liberal, 10-IV-1894, y "San Francisco de Asís", El Liberal, 20-VIII-1894. José Echegaray se inició con "Newton", El Liberal, 27-II-1894; "El Newton del Norte (Abel)", El Liberal, 16-IV-1894; "María Tudor", El Liberal, 31 IV-1894; "Hildebrando", El Liberal, 20-V-1894; "Pericles”, El Liberal, 8-VI-1894, y "El alcalde de Archidona", El Liberal, 30-VII-1894. De Ramón de Campoamor no he hallado ninguna colaboración. En cualquier caso, entre enero y septiembre de 1894, se cuentan hasta 36 colaboraciones que merecerían un análisis monográfico. Las firman, además de los citados, políticos como Cánovas, Pi y Margall, Silvela; escritores como Pardo Bazán (2), Sellés, Picón, José Fernández Bremón y filósofos y ensayistas como José Castro y Serrano, Rafael Salillas, Urbano González Serrano o Juan Pérez de Guzmán.

81 Ni durante el mes de mayo, ni en los dos siguientes se registra esta colaboración de Sagasta.

82 Por estas fechas la relación era todavía bastante cordial y hasta pensaban en nuevas colaboraciones: cuentos, sin duda. 